Arch. hist. jap. Vol. 19, n. 1 (February 1960).

P. 29-37.

1st Anat. Lab. (Head: Prof. R. URA), Tohoku Univ. School of Med., Sendai.

\title{
Quantitative Study on the Motor Facial Nucleus.
}

\author{
顔面神経運動核の定量的研究.
}

\author{
Yuzo AKASAKA, Sunao SAKAI, Yasushi KASHIWA \\ and Hiroshige SHIMADA. \\ 赤坂祐三, 酒井直, 柏康と島田広重.
}

(Received September 22, 1959.)

There have been very many research reports on the motor facial nucleus in the past, but as we could ascertain, there have been none on a quantitative study on it. The degree of development of the nucleus has been discussed relying solely on the impressions obtained in examining microscopic sections - a procedure very unsatisfactory from the view-point of comparative anatomy.

So, the present authors attempted a quantitative study of the subject nucleus with the aim of indicating its development by means of precise values. First we counted the number of cells in the right and the left halves of the nucleus of the animals examined on the serial sections and summed up the figures. Such an absolute number of the cells, however, is too sensively subject to the effect of difference of the relative size of the total brain of the animals for the purpose of comparative study. Therefore, we chose the level where the trochlear nerve just depart from the brain stem as representing its standard cross-section, and measured the total area of the tegmentum at this level (including both the right and the left halves) with a planimeter. Then, the ratio of the above absolute number of the nuclear cells to the area of the tegmentum was calculated, to determine the relative unmber of the nuclear cells for use in the comparative study.

As materials of the study brain specimens of man, 14 Simiae, 2 Prosimiae, 17 Carnivora, 11 Ungulata, 3 Cetacea, 6 Rodentia, 4 Chiroptera, 3 Insectivora, 9 Edentata, 9 Marsupialia, 4 Monotremata ( 83 species of mammals in total), domestic fowl (cock and hen), 6 reptiles and a frog (91 species in total) were used. Each specimen consisted of serial PAL-carmine stained transverse sections.

\section{Findings and Discussion.}

The cutaneous musculature consists of the major part of that covering the trunk and the limbs and that covering the head and the neck. As is well known, the former part is called the panniculus carnosus, while the latter consists only of a m. sphincter colli in lower animals and with the advance of the animal in evolution, this muscle differentiates into the various muscles in the head and the neck. The muscle originally receiving its nerve supply from the subject motor facial nucleus was the $\mathrm{m}$. sphincter colli, which is present in its typical form in the classes of birds and below, but in mammals, is barely observable in Monotremata alone, being dif- 
ferentiated into the platysma and various face muscles, as stated above, in the higher orders. During the process of the differentiation, the superficial layer of the m. sphincter colli becomes the so-called platysma myoides; " which further dif-

$0 \quad 100200300400500600700800900$

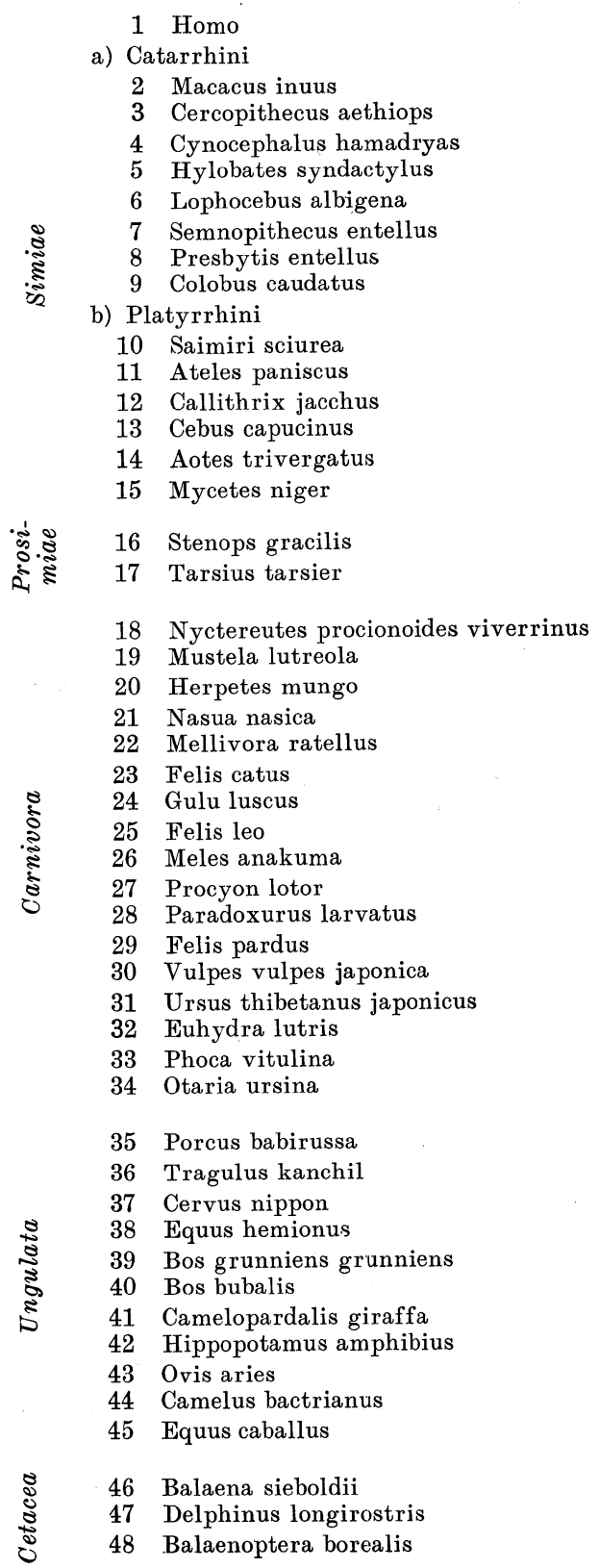

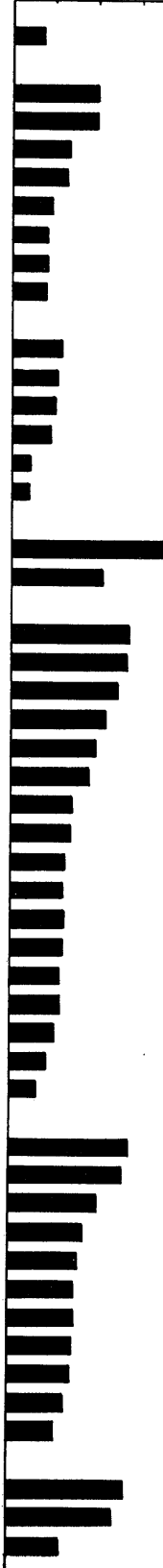




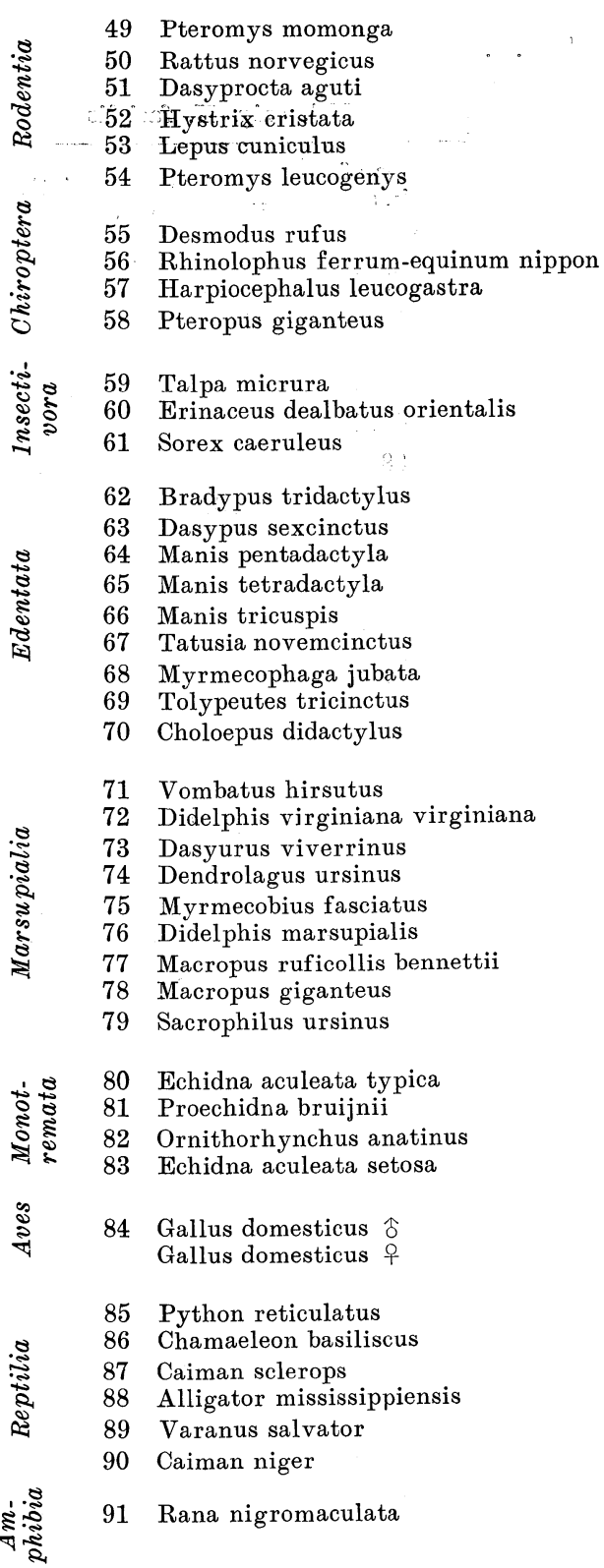

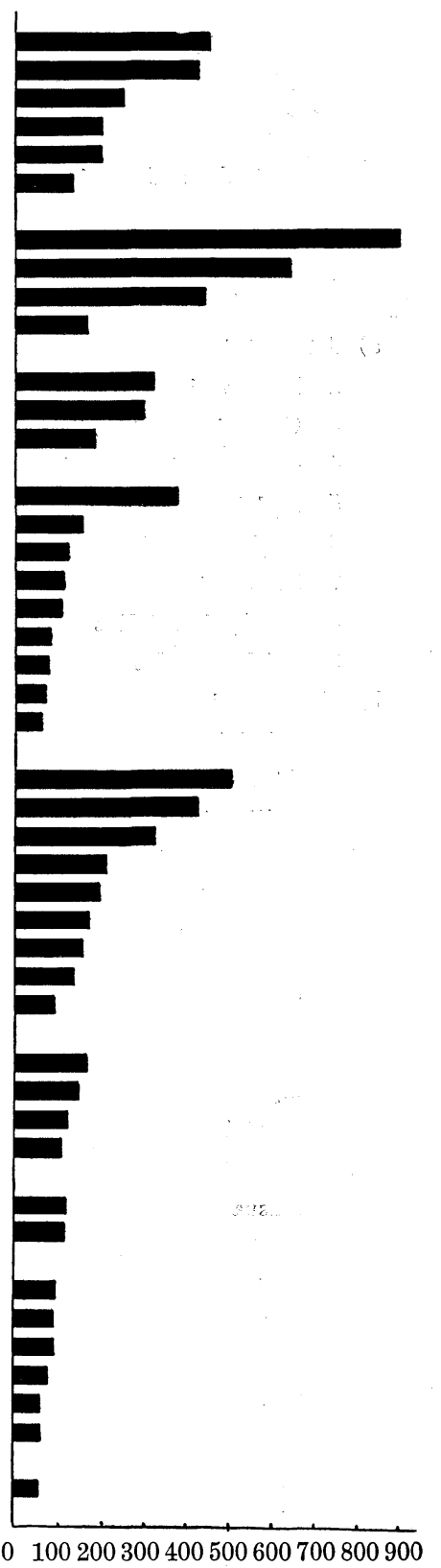

Fig. 1. Relative cell-number of the motor facial nucleus.

ferentiates into the many face muscles, while its deeper layer differentiates chiefly into the cutaneous muscles concerned with the mouth, as already described in past literature. 
Tab. 1.

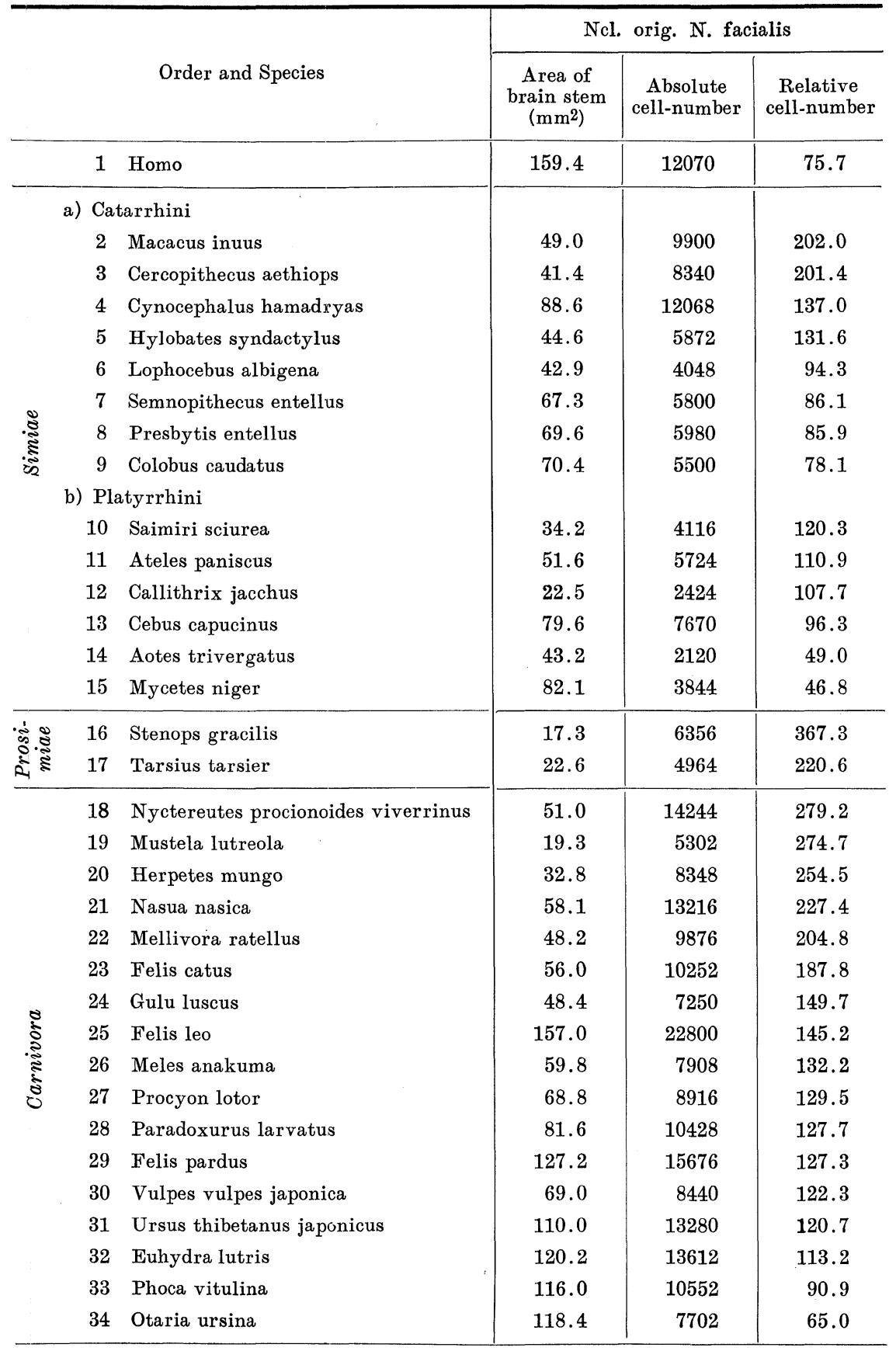




\begin{tabular}{|c|c|c|c|c|c|}
\hline \multirow{11}{*}{ 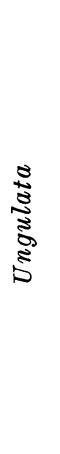 } & 35 & Porcus babirussa & 65.0 & 18400 & 283.0 \\
\hline & 36 & Tragulus kanchil & 47.5 & 12686 & 267.0 \\
\hline & 37 & Cervus nippon & 139.0 & 29644 & 213.2 \\
\hline & 38 & Equus hemionus & 170.7 & 30800 & 180.4 \\
\hline & 39 & Bos grunniens grunniens & 176.5 & 29492 & 167.0 \\
\hline & 40 & Bos bubalis & 223.2 & 35536 & 159.1 \\
\hline & 41 & Camelopardalis giraffa & 77.5 & 12276 & 158.4 \\
\hline & 42 & Hippopotamus amphibius & 221.0 & 34112 & 154.3 \\
\hline & 43 & Ovis aries & 125.0 & 18690 & 149.5 \\
\hline & 44 & Camelus bactrianus & 195.0 & 26620 & 136.5 \\
\hline & 45 & Equus caballus & 283.2 & 31700 & 111.9 \\
\hline \multirow{3}{*}{$\begin{array}{l}8 \\
8 \\
0 \\
0 \\
0 \\
0 \\
0\end{array}$} & 46 & Balaena sieboldii & 267.5 & 73390 & 274.3 \\
\hline & 47 & Delphinus longirostris & 226.5 & 55956 & 247.0 \\
\hline & 48 & Balaenoptera borealis & 581.5 & 72824 & 125.2 \\
\hline \multirow{6}{*}{ 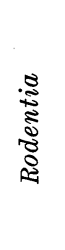 } & 49 & Pteromys momonga & 20.9 & 9620 & 460.2 \\
\hline & 50 & Rattus norvegicus & 19.4 & 8396 & 432.7 \\
\hline & 51 & Dasyprocta aguti & 38.1 & 9792 & 257.0 \\
\hline & 52 & Hystrix cristata & 78.9 & 16020 & 205.0 \\
\hline & 53 & Lepus cuniculus & 51.8 & 10592 & 204.4 \\
\hline & 54 & Pteromys leucogenys & 33.2 & 7822 & 135.6 \\
\hline \multirow{4}{*}{ 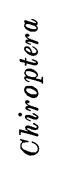 } & 55 & Desmodus rufus & 6.0 & 5428 & 904.6 \\
\hline & 56 & Rhinolophus fertum-equinum npipon & 9.7 & 6292 & 648.6 \\
\hline & 57 & Harpiocephalus leucogastra & 19.3 & 8644 & 447.8 \\
\hline & 58 & Pteropus giganteus & 21.2 & 3618 & 170.6 \\
\hline \multirow{3}{*}{ 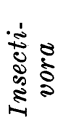 } & 59 & Talpa micrura & 13.3 & 4370 & 328.5 \\
\hline & 60 & Erinaceus dealbatus orientalis & 21.8 & 6664 & 305.6 \\
\hline & 61 & Sorex caeruleus & 34.5 & 6660 & 193.0 \\
\hline \multirow{9}{*}{ 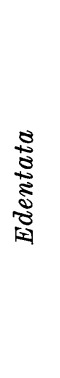 } & 62 & Bradypus tridactylus & 17.2 & 6648 & 386.5 \\
\hline & 63 & Dasypus sexcinctus & 40.4 & 6736 & 166.7 \\
\hline & 64 & Manis pentadactyla & 42.4 & 5604 & 132.1 \\
\hline & 65 & Manis tetradactyla & 41.8 & 4910 & 117.4 \\
\hline & 66 & Manis tricuspis & 37.6 & 4184 & 111.2 \\
\hline & 67 & Tatusia novemcinctus & 49.6 & 4246 & 85.6 \\
\hline & 68 & Myrmecophaga jubata & 48.6 & 4060 & 83.5 \\
\hline & 69 & Tolypeutes tricinctus & 50.5 & 3988 & 78.9 \\
\hline & 70 & Choloepus didactylus & 65.6 & 4480 & 68.2 \\
\hline \multirow{5}{*}{ 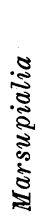 } & 71 & Vombatus hirsutus & 39.5 & 20024 & 512.4 \\
\hline & 72 & Didelphis virginiana virginiana & 17.3 & 7476 & 432.1 \\
\hline & 73 & Dasyurus viverrinus & 22.4 & 7540 & 336.6 \\
\hline & 74 & Dendrolagus ursinus & 39.7 & 8628 & 217.3 \\
\hline & 75 & Myrmecobius fasciatus & 33.7 & 6824 & 202.4 \\
\hline
\end{tabular}




\begin{tabular}{|c|c|c|c|c|c|}
\hline & 76 & Didelphis marsupialis & 38.0 & 6728 & 177.0 \\
\hline & 77 & Macropus ruficollis bennettii & 71.7 & 11732 & 163.6 \\
\hline & 78 & Macropus giganteus & 96.8 & 13938 & 143.9 \\
\hline & 79 & Sacrophilus ursinus & 75.0 & 7256 & 96.7 \\
\hline$\frac{8}{8}$ & 80 & Echidna aculeata typica & 30.0 & 5096 & 169.8 \\
\hline हूँ & 81 & Proechidna bruijnii & 31.2 & 4814 & 154.2 \\
\hline 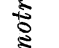 & 82 & Ornithorhynchus anatinus & 39.4 & 5018 & 127.3 \\
\hline : & 83 & Echidna aculeata setosa & 33.0 & 3764 & 114.0 \\
\hline \& & 84 & Gallus domesticus $\hat{o}$ & 24.0 & 2860 & 119.1 \\
\hline$\sum^{2}$ & & Gallus domesticus 우 & 22.0 & 2592 & 117.8 \\
\hline & 85 & Python reticulatus & 15.0 & 1416 & 94.4 \\
\hline & 86 & Chamaeleon basiliscus & 17.0 & 1530 & 90.0 \\
\hline : & 87 & Caiman sclerops & 38.0 & 3380 & 88.9 \\
\hline 范 & 88 & Alligator mississippiensis & 43.0 & 3288 & 76.4 \\
\hline & 89 & Varanus salvator & 21.0 & 1340 & 63.8 \\
\hline & 90 & Caiman niger & 45.0 & 2820 & 62.6 \\
\hline 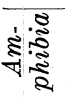 & 91 & Rana nigromaculata & 2.0 & 114 & 54.0 \\
\hline
\end{tabular}

Now, according to VERSLUYS, the dorsal part of the facialis-constrictor is said to be well developed in Amphibia and Sauropsida, but KAPPERS says that the muscles innervated by the facial nerves are still very simple in reptiles and birds and form an elaborate system only in mammals.

Our findings showed good agreement with the opinion of KAPPERS, for the absolute as well as the relative numbers of the cells of the facial nucleus in birds, reptiles and frog were very low (Fig. 1 and Tab. 1). This naturally means that the musculature supplied from the motor facial nucleus is very poorly developed in these lower animals.

In the mammals, the relative number of the cells in the motor facial nucleus was found generally much larger than that in the non-mammalian animals, vividly indicating that the facialis musculature suddenly gains in development upon passing over from birds to mammals.

Concerning the Monotremata, BRONN says that in Echidna, all the cutaneous muscles are especially well developed and KAPPERS says that the facial nucleus is large owing to the marked development of the musculature supplied with facial nerves, but according to what we have observed, the relative number of the nuclear cells in Echidna is somewhat larger than that in birds, reptiles and frog, but not at all exceptionally large and as an order, the Monstremata may be ranked in the group of generally rather low-developed facial nucleus. The Echidna, having spines on their surface, may probably have a well-developed panniculus carnosus but the cutaneous musculature receiving nervous supply from the facial nucleus cannot be very well developed. The Edentata (except the three-toed sloth) also showed low relative number of cells. 
In the mammals other than the Monotremata, as shown in Fig. 1 and Tab. 1, the Marsupialia, the Insectivora, the Chiroptera and the Rodentia generally showed large relative numbers of the cells, and the Chiroptera (except the Pteropus giganteus) showed particularly high development of the nucleus. The bats have muscles innervated by the facial nerves in their propatagium, and is may be inferred that these muscles are of high importance in their flying, so that the facial nucleus concerned with the muscles is particularly well developed in them. Pteromys momonga and Pteromys leucogenys are similarly provided with patagia, but only with plagiopatagia stretched between the fore- and the hind-limbs but no propatagium, and the facial nucleus is far worse developed than in the Chiroptera, especially in the latter Pteromys. Generally speaking, in the mammals of the lower orders the cutaneous musculature is well developed, and especially well developed in the animals having the habit of curling up their body, as is well known. In Fig. 1 and Tab. 1 we see that the porcupine, the Erinaceus and the Armadillo, the representative curl-up animals, have not very large relative cell number of the facial nucleus, the number being not the largest among the animals of the same order. This shows that the development of the cutaneous muscles in the body trunk and that of the muscles of the head and the neck do not necessarily run abreast. The generally observed good development of the facial nucleus in Rodentia, Chiroptera, Insectivora and Marsupialia, as stated above, may be considered as due to the very high development of the platysma myoides, while the m. sphincter colli has already degenerated off its original form and the face muscles are as yet not sufficiently developed as mimic muscles. In particular, such a finding may facilitate the understanding of the rather large relative number of cells shown by the mole and the rat animals which live in narrow burrows and for whom contracting the bulk of the body to the smallest volume possible is an advantage.

As a mammal rises higher in the stage of evolution, the panniculus carnosus gradually lose in development and nearly disappears in Simiae and man. At the same time, as stated above, the sphincter colli in the higher mammals lose their original sphincteric form and differentiate into the various muscles in the neck and the head. In this course of differentiation, the platysma still developed in the neck in the place of the sphincter colli in the lower mammals gradually degenerates while the face muscles become better and better developed in the higher mammals. These face muscles of course play the parts of mimic muscles and actively participate in the expression of emotion, especially well in man and simiae.

According to our measurements, the motor facial nucleus is moderately developed in Cetacea, Ungulata, Carnivora and Prosimiae, but in Simiae, it is generally very weak and conspicuously ill-developed in man (Fig. 1 and Tab. 1).

Thus, as the motor facial nucleus was found relatively very small in Simiae and man with the face muscles extremely well developed as mimic muscles but with the platysma fallen into degeneration, but very well developed in the lower mammals with the face musculature and platysma developed in the reverse direction, it may be clearly inferred that the development of the facial nucleus depends more on the degree of development of the platysma rather than that of the facial musculature, perhaps on the relative quantitative development of the two. 


\section{Summary.}

1. The relative development of the motor facial nucleus was studied, using brain specimens of 91 species of animals, including 83 mammals, the domestic fowl (cock and hen), 6 reptiles and a frog.

2. The relative development of the nucleus was determined by the ratio of the total number of the cells in the right and the left halves of the nucleus counted on the serial transverse sections of the above specimens to the area of the tegmentum of the brain stem at a certain level.

3. In the non-mammalian animals, the relative number of the cells in the motor facial nucleus is very small.

4. The relative number in the mammals was small in the order of Monotremata, generally large in Marsupialia, Insectivora, Chiroptera and Rodentia and moderately large in Cetacea, Ungulata, Carnivora and Prosimiae. In higher Primates it is small and particularly small in man. In Edentata also it is generally small.

5. A comparative study of the findings has revealed that the development of the motor facial nucleus depends more on the development of the platysma than on that of the face musculature.

In conclusion, I hasten to express my thanks to Prof. URA and Asst. Prof. YAMAMOTO of this laboratory for their kind assistance and valuable suggestions.

\section{著 者 自 抄.}

著者等は顔面神経運動核の相対的発達を調べて之を比較解剖学的に検討し，本 核の発達の相異は主によ゙の筋と関係あるかを追究する為に本研究をなした。

材料として 83 種哺乳動物, 鵴, 6 種爬虫類及び蛙, 総計 91 種動物脳の横断連 続切片標本を用いた。

本核の相対的発達を知万為に我々は左右両半の本核細胞の総数を数え, 此総数 の 1 定脳幹部被蓋横断面積に対する比を求めた (対比健).

その結果，鳥類以下の動物に於ては此対比俻が極めて小さい。哺乳類に於ては 単孔目では小さいが，有袋目，食虫目，翼手目及び噄歯目では一般に大きく，鯨 目，有蹄目，食肉目及び擬猴目では中等大である。霊長目でも小さいが人では殊 に小さく，含歯目でも亦大部分小さい.

此顔面神経核細胞数の対比值と各種動物に於ける顔面神経支配筋の分化発達の 相違とを比較検討した結果，顔面神経運動核の相対的発達は顔面筋の発達如何よ りは platysma の発達の相違に，より多く関係している事が明かである.

\section{References.}

Bronn: Klassen u. Ordnungen des Tierreichs. Leipzig, Winter, 1874-1900. - Gegenbaur: Vergleichende Anatomie der Wirbeltiere. Leipzig, Engelmann, 1898. - Hyman: Comparative vertebrate anatomy. 2. ed., Chicago, Chicago Univ. Press, 1957. - Ihle, Versluys u. a.: Vergleichende Anatomie der Wirbeltiere. Berlin, Springer, 1927. - Kappers, 
Huber a. Crosby : The comparative anatomy of the nervous system of vertebrates. New York, MacMillan, 1936. 